\title{
The hidden geographies of religious creativity: place-making and material culture in West London faith communities.
}

\author{
David Gilbert* \\ Claire Dwyer \\ Nazneen Ahmed \\ Laura Cuch Graces \\ Natalie Hyacinth
}

\author{
*Corresponding author: \\ David Gilbert, Department of Geography, Royal Holloway, University of London, Egham, Surrey TW20 \\ OEX, UK \\ Email: d.gilbert@rhul.ac.uk
}

Abstract

Religious activity, particularly as associated with what might be called everyday organized religion, has been unconsidered in recent discussions of the geographies and policies relating to creativity, and has been almost absent in the discipline of Geography's recent 'creative turn'. We argue both that religion has been given little or no attention in academic discussions of vernacular creativity, while arts policy as it developed in the UK in the post-war period has had a strongly secular focus. This continues in more recent policies and initiatives that have sought to promote the amateur and voluntary arts sectors. We explore the reasons for these absences, before turning to examples of strongly creative practice in a range of case studies, focused in a small area of suburban west London. These show a remarkable diversity of creativity including the design, construction and transformation of buildings and spaces for religious worship, but also in ritual, performance and the everyday practices of making sacred space. Our case studies include examination of performance and material culture in a Tamil-speaking Hindu temple, and in Roman Catholic, Anglican and Pentecostal churches. These include changes to architectural form, stained glass art-work, community craft projects, and musical performance and composition. We suggest that religious creativity has a hidden significance that has become more important in the UK's increasingly diverse cities and suburbs, and that significant population groups are marginalized in creativity debates and policies that focus on the secular arts. We also suggest that there are distinctive characteristics to what we describe as 'devotional creativity', particularly in different understandings of space, practice and experience. 


\section{Introduction: The creative geographies of ordinary religion}

$16^{\text {th }}$ July 2015, Shri Kanaga Thurkkai Amman Hindu Temple, West Ealing

It is the day before the start of the annual Mahotsevam festival and the temple hums with activity. ... Out back, a cluster of about fifteen women in their 50s stand about tables making garlands from bunches of market-fare chrysanthemums. These will be draped on each of the deities and on the chariots for their processions around the temple tomorrow. The women wield long white threads of cotton along their arms, and deftly, rapidly, weave onto the threads white flower heads in bunches of four, row by row, interspersing them occasionally with purple and yellow. Within two or three minutes, from thread and flowers, garlands appear before my eyes. The brick tiles of the floor are carpeted in damp green leaves and petals as hundreds of garlands are made from hundreds of bunches of flowers. ... Some of the women make simple garlands, while others make bell-like smaller shapes which they attach to their garlands, resembling necklaces with pendants. As their fingers move with speed, flowers and cotton flying, they chatter in Tamil, direct one another with pointing, inexplicably spare fingers, and bustle about, wrapping loose sari ends about them as they heft more boxes and buckets of flowers. ${ }^{1}$

[Figure 1 near here]

Each year, in early August, these garlands are taken out into the streets of West Ealing, decorating the chariots of the Hindu deities as they are processed around this part of suburban London. Estimates vary, but perhaps 10,000 people participate or watch the annual Chariot Festival, the culmination of the annual 27-day Mahotsavam Festival. ${ }^{2}$ The flower-making is only one part of a sustained effort by the Shri Kanaga Thurkkai Amman Temple (SKTA) in preparation for the festival. Other members of the Temple are involved in building and maintaining the chariots, in decorating and transforming the temple, in music-making, in cookery, and in extensive rehearsals for the rituals during the procession itself. 
These activities are imbued with creativity. In the immediate environs of the SKTA there are many other examples of faith communities involved in what also look like intensively creative practices: in making or converting buildings and spaces for religious worship, in music-making and other forms of performance, and in craftwork that makes and maintains the material culture of organized religion. Such activities, however, are rarely considered in academic work that examines significance of creativity, and in the discipline of Geography's recent 'creative turn' discussion of religion is almost completely absent. It is also notable that religious activity is also an absence in wider discussions of cultural policy. In the UK, particularly, there has been an upsurge of interest in policies that relate to the amateur and voluntary arts sectors, but these are overwhelmingly focused on a particular repertoire of secular art forms.

This paper is also informed by the recent recognition of the importance of the materialisation of faith practice and embodied performances in religious studies and the geographies of religion. ${ }^{3}$ Such work reveals plentiful evidence of activity which is sometimes organised, routine and theologically approved, but also often spontaneous, improvised and sometimes transgressive. Despite this focus on performance or embodied practices however, religion is rarely understood as being creative; indeed organized religious practice is much more often understood as ritualistic, controlled or constrained by hierarchies or liturgical rules, and in short, the antithesis of a common understanding of creativity.

Our starting point for this paper is therefore a claim that religious activity, and particularly activity associated with what might be called everyday organized religion, has been unconsidered in discussions of the geographies and policies relating to creativity. While these issues are more general in scope, and have different inflections in different contexts, our focus is on the UK, and our discussion draws upon detailed research of creativity in religious communities in Ealing and Hanwell in the West London suburbs. ${ }^{4}$ [Figure 2 near here] These case studies clearly reflect the distinctive and complex geographies of contemporary London, but we make wider claims from this research about what thinking about religion, and particularly the practices of ordinary, everyday 
religion, can contribute to thinking about the geographies of creativity, and to policy perspectives on the creativity and value of the amateur and voluntary arts sector in the UK.

In the first section of the paper, we consider the recent upwelling of interest in creativity in Geography and beyond, and particularly in 'vernacular' creativity. We explore reasons why religious practice has been almost completely absent from this work. A parallel argument is made about the relative absence of religion in wider thinking about creativity, and particularly in the development of arts policy in the UK. This absence has strong cultural roots in the development of the post-war model of arts governance in the UK. ${ }^{5}$ Although that model of state support for the arts has been severely compromised since the 1980s, its legacies remain in a more recent assertion of the significance of the independent amateur and voluntary arts sector.

In the following section, attention turns to the importance of religion practices in creative 'place-making'. We begin by asserting the continuing importance of religion, even in a context of overall decline in religious affiliation and attendance during the twentieth and early twenty-first centuries. Within London there has been a turnaround and increase in religious worship since 2000, associated with migration, with increases in Muslim, eastern European Catholic and Orthodox, and West African Pentecostal populations, as well as wider increases in attendance at evangelical churches associated with the 'new expressions' movement. For example, average weekly participation in all forms of Christian worship in London is estimated to have increased 16\% between 2005 and 2012. ${ }^{6}$ We argue further that religious groups are often engaged in distinctive 'place-making', through the design, construction and transformation of buildings and spaces for religious worship, but also through ritual and performance, and through the everyday practices of making special places, through conservation, cleaning, repair and maintenance. We then turn to the examples of our research sites, showing the intensity and diversity of creative activity and active 'place-making' in West London. 
The concluding section of the paper affirms that analyses of creativity, and particularly of vernacular creativity, need to be extended to encompass religious cultural activity, and that more dialogue between work on the geographies of religion and creativity would be fruitful. We also extend this argument outlining the distinctive character of what might be described as 'devotional creativity', and the ways it provokes different understandings of space, practice and experience.

\section{Vernacular creativity, arts policy and the hidden geographies of religion.}

Recent years have seen what has been described as a 'creative turn' in both human geography and more widely; the study of creativity is no longer restricted to the humanities, the arts, philosophy and psychology, but has become significant in understanding the nature of economies, cultures and societies, and the relationships between humans and their environments. For Harriet Hawkins, discussion of creativity is now common across the discipline of geography, but it is invoked in strikingly different forms, 'variously understood as the saviour of the economy, as a tool of neo-liberal politics and part of the diplomatic arsenal of state-craft practices, as a psychological trait and philosophical concept. It is also an embodied, material and social practice that produces both highly specialist cultural goods and is a part of everyday life, and it offers myriad possibilities for making alternative worlds.'7 ${ }^{7}$ This is a broad and generous understanding of creativity, but work in the geographies of creativity has tended towards certain kinds of practices and certain sorts of places; religious practices and spaces are largely absent in this work.

From the early 1990s, the main area of engagement with the geographies of creativity was in debates about the restructuring of certain urban economies towards the so-called 'creative industries', and their associations with certain social, cultural and spatial formations. ${ }^{8}$ However, as well as many direct 
critiques of the 'the creative city' literature, with its focus on clusters and particular forms of urban booster politics, recent approaches to the geographies of creativity have broken with the particular and partial reading of the term embedded in notions of the creative economy. Using John Holden's useful distinction, much of this work could be said to be shifting from a cultural economy approach towards an understanding of the place (and indeed the places) of creativity in a fuller cultural ecology: 'the use of ecological metaphors ... creates a rich way of discussing culture' that does not privilege financial value over other types of value. ${ }^{9}$

One such approach highlights activities that directly challenge the creative city model in its own habitat, focused on creative 'urban subversions', activities such as graffiti art, skateboarding, parcours, urban exploration and psychogeography. ${ }^{10}$ Such activities often have an explicitly countercultural or transgressive form, challenging the supposed creativity of neoliberal urban boosterism with an alternative celebration of the urban. However, as Luke Dickens' work on 'post-graffiti' indicates, the line between subversion and cooption into the commodification of categories such as 'edginess' and 'buzz' can be very thin. ${ }^{11}$ There is a kind of symbiosis between the urban boosters and these critics, and a shared fixation on the contested ground of the 'creative city' and intense clusters of metropolitan creative activity.

Other recent approaches to creativity shift attention from metropolitan elites and avant-gardes. Edensor, Leslie, Millington and Rantisi argue that 'an understanding of vernacular and everyday landscapes of creativity honours the non-economic values and outcomes produced by alternative, marginal and quotidian creative practices'.12 Such a move is both timely and important, and interest in 'vernacular creativity' has stimulated research of many forms of everyday practice. At the same time, there has been renewed interest in the idea of the 'amateur', and particularly of the significance of amateur arts, in the UK. Whereas once the term 'amateur arts' came with connotations of being secondrate, conservative, derivative, unimaginative and lacking innovation - in short, uncreative - recent work has emphasized the significance of amateur creativity 
within an ecology of culture, its interconnections with commercial and publiclyfunded arts, and its importance for everyday life. ${ }^{13}$

This upwelling of serious interest in vernacular and amateur creativity has a number of characteristics. First, it has a democratizing effect on the notion of creativity, regarding it as an element of the lives of many, rather than the preserve of professionals or exceptional artistic talents. Second, there is a remapping of the spaces of creativity. This is a move that questions the primacy of key cities and certain kinds of urban spaces as incubators of creativity, particularly gentrified centres and bohemian enclaves. ${ }^{14}$ A focus on vernacular creativity turns attention towards more 'ordinary' cities, and towards suburban, small town and rural sites. Third, there is a recalibration of the nature of creativity; as Edensor et al. argue, 'vernacular creativity foregrounds the un-hip, the un-cool, and possibly the downright square, and embraces those marginal and non-glamorous creative practices excluded from arts- and culture-based regeneration.'15 Spaces of Vernacular Creativity includes discussions of amateur musicians, rural arts festivals, photography, and community and suburban gardening. ${ }^{16}$ More recent geographical work has examined amateur choirs, knitting, craft making, amateur dramatics and the creativities of amateur enthusiast and heritage groups. ${ }^{17}$ Within this analysis of vernacular creativity there has been an emphasis on skilled practice and workmanship, processes of making and the importance of sociability and community. Given this emphasis on activities that 'are distinguished by their expression of community values and their inclusion of many participants', the parallels with creative work in religious settings by faith communities are striking. ${ }^{18}$ We suggest that there is a significant hidden geography of creativity associated with religious faith. ${ }^{19}$

The recent resurgence of work in the geography of religion has seen a renewed emphasis on the embodied, performative practices and material cultures of religious and spiritual identities. ${ }^{20}$ Work on the geographies of sacred space, and the mobilities of people in pilgrimage and of objects through religious networks, has developed interest in the continuing importance of religion in placemaking. ${ }^{21}$ There has, however, been little direct interchange with those 
developing new approaches to creativity. More generally in religious studies, its material turn has been connected to a concern for understanding people's 'lived' or 'everyday' understanding and expression of religious identity. ${ }^{22}$ For some scholars the term 'vernacular religion' captures an understanding of religion 'as people experience, understand and practice it', disrupting the boundary between concepts of 'official' and 'folk' religion. ${ }^{23}$ Reviewing the range of empirical work within contemporary religious studies it is possible to identify many examples of religious creative practice (even if rarely identified as such.) Take, for example, Harris' account of the creative embodied labour which produced a remarkable Marian shrine in Carfin in rural Lanarkshire in the 1920s. ${ }^{24}$ Or Jain's analysis of the production and circulation of Indian religious calendar art, which suggests that this is a form of vernacular creativity which intertwines the sacred, the commercial and the artistic. ${ }^{25}$ The creation and maintenance of domestic shrines or worship spaces, defined by Garnett and Harris as 'devotional materiality', is further evidence of everyday creative religious practices. ${ }^{26}$

The exclusion of religion from discussion of creativity also reflects both a very long-running cultural construction of religion that regards it as uncreative or even anti-creative, and in the UK at least, a lasting culture of secularism within arts policy. There is a powerful post-enlightenment view of creativity that has a focus on individual self-realisation, contrasting this with the supposedly passive and ritualistic practices of religion. Irving Singer in his philosophical consideration of Modes of Creativity contrasts a human and secular 'creativity' that developed from the seventeenth century onwards, with its characteristic dimensions of the 'imaginative', the 'inventive', the 'novel', and the 'original', with an older religiosity of a singular divine 'creation' with art in its service. ${ }^{27}$ In Western art, while faith and spirituality have clearly provided subjects, inspiration and influences for many major figures, both rationalism and romanticism have in different ways disparaged or marginalized religion.

In mid-twentieth century Britain, the secularization of creativity was institutionalized in the developing relationship between the state and the arts. ${ }^{28}$ After the founding of the Arts Council of Great Britain in 1946, there was a clear 
pattern to activities and spaces that were given state-support and sanction, and regarded as central to national creativity. This was a landscape of world-class arts organizations usually based in London, regional orchestras, opera companies, galleries and museums, then a more-locally based network of arts centres, primarily run by local councils. ${ }^{29}$ As critics of the Arts Council noted, this had the effect of defining the arts as certain kinds of activities concentrated in state-aided organizations in state-supported venues, marginalizing both commercial and amateur arts, but it also created a strongly secular institutional structure and habitat for the arts. ${ }^{30}$ In turn, the main religious organizations, particularly the Anglican and Catholic churches, had no willingness or incentive to work with the state-sponsored arts sector. The great cathedral choirs, while clearly recognized as music-making institutions of the highest quality and an important element in national culture, tended to be set to one side in discussions of official arts policies; an organization like the Royal School of Church Music, established in the 1920s to support and train musician and choristers in more ordinary Anglican parishes, operated as a charity, outside the normally recognized boundaries of the arts sector. The decline in church attendance strengthened the sense that these activities were marginal and increasingly residual elements of national culture.

A sense of the unimportance and decline of religious practices, and their position outside of policy discourses about creativity has continued in more recent moves that re-evaluate the amateur and voluntary sectors in the UK. The influential report 'Our Creative Talent' for the Department for Culture, Media and Sport (DCMS), published in 2008, criticised policy makers for failing to engage with the voluntary and amateur arts sector, stressing its importance in the 'arts ecology' and its impact in developing 'vibrant and inclusive communities.' ${ }^{31}$ The report identified the scale of participation in the sector, estimating that there were around 50,000 active amateur and voluntary arts groups in England in 2007, 5.9 million members putting on around 710,000 performance, exhibitions and other events, with combined attendances of 159 million. The report recognised both the importance of the relationship between this sector and the professional arts, and its significance in many lives. More recently the UK Arts and Humanities 
Council (AHRC) Cultural Value project has sought to challenge the value structures of formal cultural provision that has 'frequently neglected or denigrated' amateur arts. ${ }^{32}$ In this revaluing of amateur and voluntary arts, there remains, however, a clear sense of the kinds of creative practices that are being prioritised, and an ambivalent relationship with religious organisations. For example, in the in-depth qualitative research for 'Our Creative Talent' involving interviews with representatives of 71 organisations covering craft, dance, literature, film and video, music, theatre and visual arts, not one was from a religious organisation. ${ }^{33}$

This absence of religion in academic and policy debates is a significant oversight. Despite debates about 'post-secularism' and questioning of simplistic secularisation models, there is still a tendency to ring-fence religion, as a separate and often residual sphere of social and cultural life, important in its own terms, but marginal to wider developments. We suggest three reasons for a re-evaluation of the significance of religion in discussions of creativity in the UK. The first of these is a straightforward recognition that organised religion, while not practised by a majority, is still much in evidence, is important socially, and still a cultural form of significance for millions. While there is a long-term overall decline in religious attendance and observance, a significant proportion of the population worships regularly. In Christianity, regular Sunday attendance has declined for Anglicanism, with an estimated decline in England of 14\% between 2000 and 2010, Catholicism (-16\%) and Methodism (-39\%); by contrast, regular worship at Pentecostal churches in England increased by $40 \%$ in the same period, with much of this growth concentrated in London. ${ }^{34}$ Brierley estimates an average 'usual Sunday attendance' at Christian worship of around $2.75 \mathrm{~m}$ people in England in 2015. ${ }^{35}$ Figures for other faiths are not produced systematically, but very broad estimates of the number of regular worshippers can be made, suggesting that around 1.25m Muslims are regular worshippers, and perhaps $0.6 \mathrm{~m}$ people of other major faiths. ${ }^{36}$ These estimates suggest a total annual attendance at worship in England and Wales in excess of $200 \mathrm{~m}$, and possibly as high as $250 \mathrm{~m}$; as cultural activity this can be compared with the 2007 
estimate of $159 \mathrm{~m}$ for attendance at amateur and voluntary arts events in 'Our Creative Talent'. ${ }^{37}$

A second reason for taking religion seriously concerns the relationship between religious practice and the changing character of British society. The steady decline in Christian worship that was a characteristic of the twentieth century has been slowed significantly by recent migration, particularly Catholics from Poland, Orthodox from Romania, and Pentecostals from West Africa. The increase in 'black-majority churches' (BMCs) has been particularly striking in London, where of the 900 new churches (mostly Pentecostal and other smaller denominations) that opened between 2005 and 2012, over 400 were BMCs. ${ }^{38}$ Over a longer period, Muslims, Hindus and Sikhs have become a much larger proportion of the actively religious population. Assessments of the strength of everyday creativity, and policy responses and recommendations, have often identified migrant and BME populations as under-represented in the amateur arts. This is in part reflects assumptions about the standard forms of creativity that underpin the approaches of academics, policy-makers and key umbrella organizations like Voluntary Arts England. Academic interest in creativity and multiculturalism has often focused on organizations like the Rich Mix Centre and Institute of International Visual Arts in Tower Hamlets in East London, rather than the more widespread everyday creativities expressed in diasporic faith groups. ${ }^{39}$ This is highlighted in Jasjit Singh's 2014 review for the Arts and Humanities Research Council (AHRC), which acknowledges the secular multiculturalist framing of much of the arts practice grouped under the umbrella of 'South Asian Arts.' Singh highlights the importance of religious spaces for music and dance and emphasises 'the role of the arts in religious and cultural transmission'. He suggests that an understanding of the cultural value of South Asian arts requires an examination of 'the lived experience of participation in these arts' pointing out that many more people encounter South Asian cultural forms in temples or local religious events than commercial cultural venues. ${ }^{40}$

Finally, religion needs to be taken seriously in considerations of creativity because of the density and intensity of its effects in place-making. In the UK, this 
must be set in a context of neoliberalism, the political economy of 'austerity', and sustained pressure on the local state. The post-war model of state-supported arts with local authorities as key providers through arts centres, libraries and other public spaces has been greatly degraded. There has been a longer catastrophic decline in spaces associated with other civil society organizations, that were important sites of cultural activity up to the 1980s. In urban and suburban landscapes, the agency of ordinary citizens to creatively make places and even individual buildings has declined significantly; a weakened local state and a planning system under extreme strain has given more and more power to commercial developers and corporations in place-making. There are some recent examples in the secular amateur arts sector of initiatives in place-making, such as National Lottery supported schemes to rebuild or refurbish local theatres, or 'pop-up' opportunities, particularly in areas with significant closures to traditional retail premises. However, such developments in the secular voluntary and amateur arts sector are far less common than the making and remaking of buildings and spaces by religious groups.

There is an extensive literature that charts the changing geographies of religious buildings in Britain, considering the closure or conversion of redundant churches, and the planning and building of new religious spaces. ${ }^{41}$ As well as discussion of the planning and politics associated with landmark buildings, there has also been significant attention played to the widespread change in more ordinary buildings and landscapes of religious faith. ${ }^{42}$ However, while the scale of these changes has been recognised, what has been overlooked is their significance as actively creative interventions in urban, suburban and (more rarely) rural landscapes. Historic England has recently commissioned research on minority faith buildings, with a particular focus on how historic buildings (often former churches) are maintained and adapted. However their focus is primarily on the preservation of the historic built environment rather than documenting creative architectural and artistic responses such as the extravagantly painted ceiling of Bolton's Swaminaryan Hindu Temple. ${ }^{43}$ This has begun to change, with recent recommendations on the relationship between faith groups and the planning system stressing the importance of the creative 
and place-making capacities of religious groups, particularly in countering negative responses and objections to new developments. Other pioneering projects have celebrated British Muslim art and heritage, extending discussion of creativity beyond the architectures of faith, to wider dimensions of material culture. $^{44}$ Our research on the place-making of religious communities in West London reveals a trajectory of improvisation, reinvention and innovation often sustained by partnerships between professional and amateur artists, and the everyday creative energies of religious congregations.

\section{The creative geographies of everyday religion in West London}

To develop this argument about the creative work of faith communities, we focus on examples from research in West London, geographically concentrated in the London Borough of Ealing. Ealing is a diverse multi-ethnic and multi-faith borough. The western portion of the borough, Southall, is well-known as one of the most important sites in the South Asian diaspora, the eastern part of the borough, Acton, has an association with migration from the Caribbean and since the 1990s, West Africa. Ealing as a whole has been a major destination for Polish migration, both in the immediate post-war period, and particularly since EU enlargement. Ealing has also been influenced by the changing pressures on London as a global city, most notably through property inflation and growing inequalities between owner-occupiers and others. Currently the character of what was once thought of as archetypal London suburbia is being changed by large speculative apartment developments particularly around the main transport hubs. ${ }^{45}$ Nonetheless, the central part of the borough where our case studies and examples are concentrated, retains a strong sense of being very ordinary, a landscape of semi-detached and terraced houses, some social housing, of congested major roads, and commuter tube and rail stations.

The religious diversity of the area is evident both its demography, but also in what might be described as a dense geography of everyday religion. Using a combination of official registrations, local publicity and tagging of places of 
worship on Google Maps and OpenStreetMap, we estimate that there are over 50 separate sites of worship in the 6 census wards covering central Ealing and Hanwell. This is an undoubtedly an underestimation with some congregations sharing one site with others worshipping in more temporary spaces such as schools, halls and houses. A good example of shared premises is the Anglican Church of St John's in West Ealing which is also the home for three other Christian churches: Living Water Arabic Church, the Myanmar Christian Fellowship, and the Ark of Salvation Russian Church. ${ }^{46}$ The development of new religious spaces, and the transformation and repurposing of buildings for religious use has had significant academic attention (while not always framed in terms of creativity), but far less attention has been given to other aspects of religious activities. ${ }^{47}$ Our discussion here turns to the creative work that makes and maintains the material and performative culture of religion.

\section{Preparing for Mahotsavam: decorative artists and flower garlands}

Our opening vignette foregrounded the SKTA temple and its annual Mahotsavam festival. This thriving Sri Lankan Hindu temple is housed in a former Baptist chapel that has undergone an incremental 'Hinduisation' of its interior and exterior, working within with limits proscribed by a local heritage listing. This work has a transnational form. The ornate vibrant shrines inside the temple were designed and painted in South India, their dimensions and positioning in the temple carefully orchestrated by priests in both South India and Ealing. Many interior elements, such as the vast, intricately carved wooden doors and frames, were installed on site by a specially trained religious sculptor, travelling back and forth from South India on a religious worker visa. Decorative work is also undertaken by volunteers, and on occasion, elements of the building are commissioned simply on the whim of temple committee members, resulting in an eclectic space. Thus recent decorative fibreglass window frames were ordered from India by the current Temple chairman and painted by their resident sculptor onsite. According to the chairman, they serve no specific theological function, but were commissioned by him personally (rather than through recommendation by the priests) to make the plain interior of the Baptist church 'look beautiful'. 
This Hindu temple can thus be understood as a site of vernacular creative placemaking which combines the skills and expertise of transnational itinerant artists with a bricolage approach to religious decoration. Religious authority is not always sought for decorative changes and additions are incremental and sometimes spontaneous. In summer 2015, a plywood structure was installed on the exterior of the buildings for the Mahotsavam festival. The structure was lightweight and designed to be lifted off if required, in line with temporary planning permission. This 'temporary' structure remains in place, and was extended for the 2017 Festival, suggesting that incremental 'Hinduisation' of the building is largely uncontested. The structure was designed and constructed by a pair of professionally trained sculptor-carpenters from Sri Lanka. They undertake paid design work for temples in the UK and Sri Lanka, but their work for the West Ealing temple was offered in kind. That work was treated as devotional and religious duty to what they regard as their local temple. [Figure 3 near here]

In the weeks preceding the Chariot festival, intense preparations take place including the making of many hundreds of floral garlands for a succession of ceremonies. As detailed above, the garlands are usually made by male South Indian resident priests, but before the festival the sheer volume required means that volunteer help is needed. A dedicated team mostly middle-aged women, work together making garlands. Technically, they are supervised by a young male priest, but are very much in control of the proceedings. This is both a skilled repetitive ritual of craft making, as flower heads are expertly attached to cotton threads with flying fingers, but also a site of innovation revealing the evolution of a migrant religious community. None of the women had previously made garlands in Sri Lanka, a task usually reserved for priests. There is evident pride and ownership in their accomplishment. The garlands can be placed alongside other devotional objects, such as the ghee candleholders that are handmade from fresh limes by women at the temple every Tuesday. The SKTA temple is a dynamic site of Sri Lankan Hindu identity and worship where material cultures are constantly reshaped by new migrants, with different skills from earlier generations. 


\section{Renovating Our Lady and St Joseph's: the lightbox window}

The Roman Catholic Church of Our Lady and St Joseph's was built in 1967 to house an expanding Catholic congregation which had outgrown the existing church (constructed in 1860 by Edward Pugin, son of Augustus Welby Pugin for a congregation of primarily Irish migrants who came to build the viaduct on the Great Western Railway). In 2010 the energetic parish priest, Bernard Scholes embarked upon church renovations intended to reinvent a 'dull, gloomy' 1960s building, making it a 'warm, welcoming space.' Alongside the painting of the interior, the opening up of the sanctuary with a new curved staircase and lighting, the 2010 renovations included the design and making of a striking piece of stained glass that now hangs behind the large crucifix. The stained glass 'window' is in fact a lightbox, lit from behind, since church authorities ruled out a new stained glass window on the grounds of practicality and cost. It was designed by artist-parishioner Martin Jarvis and made by a locally-based, and largely self-taught, stained glass window artist, Sophie de Souza, who belongs to a neighbouring Catholic parish.

Martin's design for the window drew on his deep personal connection to the space of the church, and his ideas evolved over a long period of time. The final piece was designed to be both sympathetic to its original surroundings and to reinvigorate the church's interior. The existing cross, previously located on the back wall, had been gifted from a nearby hospital chapel, where many of the Irish congregation in the 1950s and 1960s had worked. Jarvis' design was intended to rework the its meaning, as he explained:

'One of my main ideas was to take that giant crucifix off the sanctuary wall. It always disturbed me that it was very much the dead Christ... I felt that we needed to put it in context ... there needs to be resurrection there too'. ${ }^{48}$

His resurrection window design used the colour schemes of the existing stained glass in the church, abstract dalle de verre work by ecclesiastical firm Gibbs and Goddard who produced similar work for many post-war Catholic Churches. When the window was rejected by the church authorities, local artist Sophie de 
Souza designed a lightbox to be installed behind the large crucifix. Sophie's creative interventions came in the form of the technically innovative design of the lightbox, selecting the appropriate and most effective colours for the glass, which required much experimentation, and painting of several layers of colour to produce the required effects. The final design was approved by the congregation and its purchase made possible by parishioners who each sponsored a piece of glass in the window. The window itself was theatrically revealed to the congregation (having been covered during its construction) when the lights were switched on for the first time at the re-dedication of the new church in 2010.

[Figure 4 near here]

This example unites a parish congregation, an imaginative parish priest and two local parishioner-artists in a creative response to the renovation of an ordinary suburban church. The example is not unusual, and many religious communities are involved in decisions about the renovation of their faith buildings including the commissioning of new art works. What we want to highlight from this example is the creative agency afforded by artists who were also parishioners. This is another example of the porosity of the divide between 'professional' and 'amateur' highlighted in current work on geographies of creativity. Yet here both artists also draw on their own lived religious identities to inform their arts practice. Their art-work is a creative response to the making of sacred space which is embedded in their own religious identity and shaped by local worship practice and experience. It is also a creative practice developed in partnership with the priest, who has his own theology of the church space, and the congregation.

\section{Sacred stitching: kneelers at St Thomas the Apostle Anglican Church, Hanwell}

Visitors to the Anglican church of St Thomas the Apostle in Hanwell are impressed by the simplicity of the architecture of its architect, Edward Maufe, who later developed this design in Guildford Cathedral, or the wealth of art work by such luminaries as Eric Gill or Vernon Hill. ${ }^{49}$ If the architecture and artwork of this suburban church provides one narrative about the relationship between creativity and religion, there are also examples of more vernacular creativity. 
Resting on the wooden chairs in the nave, scattered in the children's corner and at the altar of the Lady Chapel, are more than sixty hand-stitched kneelers which were completed by parishioners in the 1970 and 1980s. The 'kneeler project' was initiated by Daphne Cornish, a talented embroiderer and member of the Embroiders' Guild and was perhaps inspired by the extensive handmade kneelers in Guildford Cathedral. The kneelers are themed by colour: one set represents different organisations in the church, such as the Girl Guides, Brownies and Choir; another depicts local landmarks including the Hanwell viaduct, the E3 bus, the M4 motorway and Heathrow airport. Designs were sketched onto graph paper and then colour-coded for the embroidery. The kneelers were completed by individuals and groups (some named on the reverse) over several years. The standard of work is uneven reflecting different levels of skill and expertise or, as in the case of the kneeler completed by the Brownies and Girl Guides, multiple makers.

[Figure 5 near here]

Interviews with those who made the kneelers emphasise the social and communal pleasures of working together and the skills developed. ${ }^{50}$ This echoes wider work on home craft that has re-valued such work and the skills involved, rescuing it from the condescension of those who deride it as uncreative domesticity. ${ }^{51}$ Clearly the kneelers involved creative design (most notably in the motifs chosen for their design) and the development of skills amongst those who made them. They also rework links between the religious and the domestic, while many of the women who made them also knitted and sewed for their own families, they also made objects to sell at the annual church bazaar and to send to those in need at home or abroad. The archives of the church reveal a network of creative endeavour supporting transnational religious geographies of mission and philanthropy. Makers of the kneelers reflected that they were 'a gift to the church', an opportunity to celebrate the work and history of this parish community. Thus the kneelers emerge as a creative engagement to making tangible the spiritual and social value of the faith community embedded within a longer tradition of religious craft-making in the parish. The kneeler collection is a form of vernacular religious material culture that is worthy of critical attention from both historians of religious textiles and vernacular needlework. However 
they are not unusual and research in many of the other churches in the vicinity reveals a wealth of church textiles made by parishioners including banners, quilts and wall hangings as well as vestments and altar clothes.

\section{Musical performance and production at the Ealing Christian Centre}

Ealing Christian Centre (ECC) is situated near Northfields Underground station is housed in a former 1930s cinema. The conversion of the building in 1995 to a place of worship highlights this Elim Pentecostal church's flexible approach to sacred space and its distinctive place-making. ${ }^{52}$ The creativity running through ECC's ethos is also evidenced in quality of music performed and practiced in the church. 'Celebrations' occur every Sunday morning at 9.30am and 11.15am with over a thousand worshippers attending each week. Music is performed by ECC's dedicated worship team, an in-house church band consisting of drummers, keyboard players, guitarists and singers. The first half-hour of each service is led by the worship team who guide the congregation through a series of contemporary, affective Gospel songs. The worship team encourage a call and response musical dynamic in which the congregation are not just listeners but active performers and participants of the musical performance themselves. The words are projected onto a large screen above the stage to enable worshippers to move their bodies freely. Worshippers are encouraged to sing and dance along to the music in their own individual ways, to feel unrestricted by routine or ritual. Emotive and spontaneous responses to the music are attributed to the presence of the 'Holy Spirit', but the affective power of the music draws upon the quality of the music-making from a mixture of volunteers and semi-professional musicians.

[Figure 6 near here]

The distinctive nature of ECC's musical offering includes composition as well as performance. A number of the songs performed each Sunday are composed inhouse for Elim Sound, Elim's international record label. Songs such as 'Power in the Blood' were composed by Pastor Sam, ECC's Music and Worship Leader for the Elim 100 album. The album, released to celebrate Elim's centenary, went to number one on the UK iTunes Gospel music chart. ECC also has an in-house professional-standard music studio where Kingdom Collective, three long-term 
members of the church, produce music. In interviews, Kingdom Collective emphasized their aim of musical excellence and their wish to be seen as the same quality as secular musician counterparts. Aware that explicitly Christian music is often disparaged or marginalized, the artists based at ECC produce music that is both influenced by popular styles such as R\&B and hip hop, but that is also in line with their spiritual beliefs. Kingdom Collective counter this perception of religious music by emphasizing the qualities of their artistry, creativity and musicianship. In interview, J.O. of Kingdom Collective stressed that "we are not Christian artists. We are artists who are Christian."53 Mr. K., a spoken-word artist and rapper also based at ECC similarly wants his music to move beyond the sacred/secular divide. Like Kingdom Collective he views his music as a type of "ministry", seeking Christian and non-Christian audiences alike. Mr. K. suggested that his music-making had reach beyond religious space: "people who may never step into a church ... need to hear this. So I need to be where they are". ${ }^{54}$ Elim Sound, the ECC music studio and ECC artists all work within a growing network of UK contemporary Pentecostal music that takes a commercially creative approach.

The focus upon the creativity in both performance and composition fits ECC's ethos that creative talents should be celebrated and nurtured, as expressions of the divine in everyday life. Pastor Richard, ECC's senior church leader, views these talents as "gifts" that are evidence of God's work on earth. 55 Pastor Richard describes the body as designed for worship and music, and that being creative is a natural extension of being spiritual beings. ECC actively encourages the creative expression of music through its Youth Ministry where Pastor Sam teaches and mentors many of the young members in music. The also worship team are also highly accomplished musicians who draw on professional backgrounds to enhance the experience of music at ECC. Some sing professionally with the London Community Gospel Choir, have music degrees or record and release their own music independently. More generally, ECC regards creative expression as a gift from God to be nurtured and celebrated, and an important way of expressing personal faith. However, such commitment to a creative and personal relationship leads to a creative culture that is both 
strongly collective, and which encourages both excellence and entrepreneurship in the service of faith.

\section{Conclusion: Hidden geographies of religious creativity}

These activities clearly demonstrate the richness of the creative culture of religious life in a West London suburb. Our argument is not that this the cultural experience of the majority of people in Ealing or more generally, and is certainly not a singular unified religious culture. What we do claim is that this cultural activity is at least as significant in terms of participation and engagement as the secular activities that are more usually associated with the amateur arts or discussions of vernacular creativity. Religious organizations have been particularly significant in activities that can be described as 'creative placemaking', altering the nature and experience of places and built spaces, particularly on a very local scale.

Our first conclusion is that this kind of creativity has been hidden or marginalized, in both academic discussion of creativity and in policies that address popular arts participation. We suggest that there is productive dialogue that can take place between those exploring the geographies of creativity and work on the geography of religion, for example in relation to approaches to sacred space. Treating the making, maintenance and remaking of sacred spaces as a creative activity adds a distinctive dimension to approaches that have emphasized either their social construction or their affective and emotional qualities. ${ }^{56}$ Similarly, work on vernacular creativity addresses rather different groups of people and different places if extended to include these practices. In terms of policy, the extension to consider faith groups and activities as a part of 'our creative talent' has the potential to make a more inclusive arts policy, widening its reach. This is not primarily about funding, and there are potentially difficult issues involved where public money directly supports faith groups. There are, however, clear benefits in treating religious creativity as an important element of the 'creative ecology'. Doing so opens up more possibilities for hybrid events and activities that cut across the sacred/secular divide, and enables 
connections to be made between creativity in faith communities and wider professional and training organisations in the arts.

A second conclusion considers the nature of religious creativity. One consequence of a focus on this activity is that it questions common assumptions about types of creativity. For example, thinking about everyday religious creativity strains our sense of the amateur and professional. At one level our research reinforces what Leadbeater and Miller called the 'Pro-Am' nature of many creative practices. ${ }^{57}$ In some ways priests, musicians and choir leaders are like professional teachers and managers in other contexts; a Hindu temple flyingin and paying specialist singers and dancers from Sri Lanka has parallels with paying soloists or lead actors in amateur concerts and theatrical productions. However, religious creativity may blur the separations between 'amateur' and 'professional' in quite distinctive ways. Clearly there are plenty of examples of secular amateur creativity that becomes the central meaningful activity in someone's life, and among groups such as retirees or the unemployed this may be very common. With religious creative activity however this distinction may be transcended; for some, what we describe as acts of 'devotional creativity' are part of a holistic view of life and its central purpose. This is creativity that has at its core a connection with the transcendent, not just self-expression and personal development, or social bonding and community building, or economic benefit.

Finally, paying close attention to the hidden geographies of religious creativity indicates unexpected characteristics of organised religion. Even if some faiths reject any theological sacredness for their spaces of worship, there is in all our case studies an active form of place-making. That creative place-making works both through the transformation, care and repair of spaces, and through the ways that such spaces are continually made and remade through religious ceremony and performance. There is creative agency in these responses to local circumstance and material culture, which confounds a sense of religion as passive and conformist, working only within the strictures of given theology and ritual. Indeed, this emphasis opens up different ways of thinking about liturgy, not as a fixed set of rules for religious observance and worship, but as a 
framework in which there may be informal, creative and sometimes surprising developments. As theologian Thomas Csordas has suggested, 'creativity is to be found not only in one instance or moment but also in the dialectical relations between ritual and social life.' Religious rituals 'are seldom mere repetitions of fixed texts. ${ }^{58}$ These examples drawn from the rather ordinary circumstances of organised religion in West London show the ways that such creativity works not just in the textual elements of religious worship, but also in its physical settings, its performances and its material culture.

${ }^{1}$ Nazneen Ahmed, field diary entry, $16^{\text {th }}$ July 2015.

2 The community estimate that in excess of 10,000 devotees attend the festival each year.

3 See David Morgan, 'The matter of Religion', in David Morgan, ed., Religion and material Culture: The Matter of Religion (London, Routledge, 2010); Birgit Meyer, David Morgan, Crispin Paine and S. Brent Plate 'The origin and mission of Material Religion', Religion (2010) 40:3 pp. 207-211; S. Brent Plate, 'Introduction to Material Religion' in S. Brent Plate, ed., Key Terms in Material Religion (London, Bloomsbury, 2015).

${ }^{4}$ This work is part of a wider project 'Making Suburban Faith', which includes a number of research and creative initiatives combining local faith communities and artists. The research was supported by the Art and Humanities Research Council. See http://www.makingsuburbanfaith.org

${ }^{5}$ This introduction refers to the UK. The complex and changing geography of the British state(s) has meant that various bodies have held responsibility for art policy different parts of the UK, at different periods. Given the case studies, our primary focus is on policy that applied to England, and London in particular.

6 Peter Brierley, UK Church Statistics, Number 2, 2010 to 2020 (Tonbridge: ADBC Publishers, 2014), section 12.

${ }^{7}$ Harriet Hawkins, Creativity (Key Ideas in Geography) (London, Routledge, 2017), p.1.

${ }^{8}$ For a critical review of this literature see Jamie Peck, 'Struggling with the creative class', International Journal of Urban and Regional Research, 29 (2005), pp. 740-70. 
${ }^{9}$ John Holden, The Ecology of Culture: A Report commissioned by the Arts and Humanities Research Council's Cultural Value Project (Swindon, AHRC, 2015), p. 3.

10 For a review and critical discussion of such work see Oli Mould, Urban Subversion and the Creative City (Routledge Critical Studies in Urbanism and the City) (London, Routledge, 2015).

${ }^{11}$ Luke Dickens, 'Placing post-graffiti: the journey of the Peckham Rock', Cultural Geographies 15 (2008), pp. 471-96.

12 Tim Edensor, Deborah Leslie, Steve Millington and Norma Rantisi, 'Introduction. Rethinking creativity: critiquing the creative class thesis', in Edensor, Leslie, Millington and Rantisi, eds, Spaces of Vernacular Creativity; Rethinking the Cultural Economy (London, 2010), p. 1.

${ }^{13}$ Fiona Dodd, Andrew Graves and Karen Taws, Our Creative Talent: the voluntary and amateur arts in England. Report prepared for the Department of Culture, Media and Sport (Newcastle, TBR, 2008); Jane Millings and Angus McCabe, with Robin Simpson and Hamish Fyfe, Understanding Cultural Value: The Amateur and Voluntary Arts (London, Arts and Humanities Research Council, 2014), available at http://www.ahrc.ac.uk/documents/projectsprogrammes-and-initiatives/understanding-cultural-value-the-amateur-andvoluntary-arts

14 Edensor et al. Spaces of Vernacular Creativity, p. 5.

15 Edensor et al. Spaces of Vernacular Creativity, p. 10.

${ }^{16}$ See particularly, these chapters in Edensor et al. Spaces of Vernacular Creativity: Chris Gibson, Chris Brennan-Horley and Jim Walmsley, 'Mapping vernacular creativity: the extent and diversity of rural festivals in Australia', pp. 89-105; Jean Burgess, 'Remediating vernacular creativity: photography and cultural citizenship in the Flickr photo-sharing network', pp. 106-115; David Crouch, 'Creativity, space and performance: community gardening', pp. 129-140; Paul Milbourne, 'Growing places: community gardening, ordinary creativities and place-based regeneration in a northern English city', pp.141-154; Tracey Potts, 'Creative destruction and critical creativity: recent episodes in the social life of gnomes', pp. 155-169.

17 See for example, Laura Price, 'Knitting and the city' Geography Compass 9, 2 (2015), pp 81-95; Ruth Craggs, Hilary Geoghegan, and Hannah Neate, Architectural enthusiasm: visiting buildings with the Twentieth Century Society', Environment and Planning D: Society and Space, 31 (2013), pp. 879-896; Emily Falconer, Yvette Taylor, Y. and Ria Snowdon, 'Sounding religious, sounding queer: finding spaces of reconciliation through congregational music', Ecclesial Practices: Journal of Ecclesiology and Ethnography. 1 (2) (2014), pp. 229-249. 
${ }^{18}$ Ann Markusen, 'Challenge, change and space in vernacular cultural practice' in Edensor et al. Spaces of Vernacular Creativity, p. 185.

${ }^{19}$ A tantalising example is provided in Fiona Hackney's 'Quiet activism and the New Amateur: the power of home and hobby Crafts' Design and Culture 5, 2 (2013), pp. 169-193 which includes, in passing, a church banner in discussion of an individual maker's craftwork collection, p179.

20 Sara MacKian, Everyday Spirituality : social and spatial worlds of enchantment (London, Palgrave MacMillan, 2012); Julian Holloway, 'Make-believe: spiritual practice, embodiment and sacred space' Environment and Planning A 35 (2003), pp. 1961-1974; Claire Dwyer, 'Why does religion matter for cultural geographers? Social and Cultural Geographies 17 (2016), pp. 758-62.

21 See Veronica della Dora 'Infrasecular geographies: Making, unmaking and remaking sacred space', Progress in Human Geography (2016), online at https://doi.org/10.1177/0309132516666190; Avril Maddrell, 'Living with the deceased: Absence, presence and absence-presence', Cultural Geographies 20, 4 (2013), pp. 501-522; Alessandro Scafi, Avril Maddrell, Heather Walton and Veronica della Dora, Christian Pilgrimage, Landscape and Heritage: Journeying to the Sacred (London, Routledge, 2014); Veronica della Dora 'Taking Sacred Space out of Place: From Mount Sinai to Mount Getty Through Travelling Icons' Mobilities 4, 2 (2009), pp. 225-48.

22 Meyer et al. 'Material Religion', p. 209. See also Timothy Willem Jones \& Lucinda Matthews-Jones, Material Religion in Modern Britain: the Spirit of Things, (Basingstoke, Palgrave MacMillan, 2015).

23 Marion Bowman \& Ulo Valk, Vernacular Religion in Everyday Life (London, Routledge, 2012.)

${ }^{24}$ Alana Harris, 'Astonishing scenes at the Scottish Lourdes: masculinity, the miraculous, and sectarian strife at Carfin, 1922-1945', Innes Review 66 (2015), pp. 102-129.

${ }^{25}$ Kajri Jain, Gods in the Bazaar: the economies of Indian calendar art (Durham NC, Duke University Press, 2007).

26 Jane Garnett and Alana Harris, 'Faith in the home: Catholic spirituality and devotional materiality in East London', Material Religion 7, 2 (2011), pp. 299302 .

27 Irving Singer, Modes of Creativity (Cambridge MA, MIT, 2010), pp. 106-115.

28 John Maynard Keynes, the founding chairman of the Arts Council of Great Britain, was an agnostic who, according to Skidelsky 'was never able to take religion seriously, regarding it as a strange aberration of the human mind.' 
Robert Skidelsky, John Maynard Keynes: Volume 1: Hopes Betrayed 1883-1920 (London, Macmillan, 1983), p. 86.

29 This hierarchical planning worked spatially and was set out most systematically in the Arts Council publication 'Housing the Arts in Great Britain' (London, HMSO, 1959) which set out the required level of arts provision for towns and cities of various populations.

30 John Pick, Vile Jelly: The Birth, Life and Lingering Death of the Arts Council of Great Britain (Denton, Byrnmill Press, 2002), p. 56.

31 Dodd, Graves and Taws, Our Creative Talent, p. 10.

${ }^{32}$ Milling and McCabe, Understanding Cultural Value, p. 3.

${ }^{33}$ Dodd, Graves and Taws, Our Creative Talent, p. 15.

34 Peter Brierley, UK Church Statistics 2005-2015, (Tonbridge, ADBC, 2011), table 13.8.

35 Brierley, UK Church Statistics, table 13.8.

36 This is a conservative estimate based on cross-tabulated data for regular religious attendance and religious affiliation from 2011 to 2014 from the British Social Attitudes Survey. At this level of disaggregation the BSA has very small numbers of respondents in each group, and these should be treated as very rough 'ball-park' estimates. The BSA for 2014 reported $17.8 \%$ of adults attending a religious service once a month or more overall. (British Social Attitudes Information System, http://www.britsocat.com accessed $1^{\text {st }}$ Feb 2017.) In the 2011 census, $2.7 \mathrm{~m}$ people in England and Wales self-identified as Muslim (4.8\% of total population), 817,000 (1.5\%) as Hindu, 423,000 as Sikh (0.8\%), 263,000 as Jewish (0.5\%) and 248,000 as Buddhist (0.4\%).

37 Todd, Graves and Taws, Our Creative Talent, p. 15. As a further comparator, annual attendances at professional football matches is around $30 \mathrm{~m}$ per year in England and Wales.

38 Peter Brierley, Capital Growth (Tonbridge: ADBC Publishers, 2013); Andrew Rogers, Being Built Together: A Story of New Black Majority Churches in the London Borough of Southwark (London, University of Roehampton, 2013.)

39 See Graeme Evans, 'Creative spaces and the art of urban living' in Edensor et al. Spaces of Vernacular Creativity, pp. 19-32.

40 Jasjit Singh, The Cultural Value of South Asian Arts (AHRC 2014) available at http://www.ahrc.ac.uk/research/fundedthemesandprogrammes/culturalvaluep roject/research-activities 
${ }^{41}$ Simon Naylor and James Ryan, 'Mosques, Temples and Gurdwaras: New Sites of Religion in Twentieth-Century Britain' in D. Gilbert, D. Matless and B. Short, eds, Geographies of British Modernity: Space and Society in the Twentieth Century (Oxford, Blackwell, 2003); C. Peach and R. Gale, 'Muslims, Hindus and Sikhs in the new religious landscape of England', Geographical Review 95, 4 (2003), pp. 469-90; Claire Dwyer, David Gilbert and Nazneen Ahmed, 'Building the sacred in suburbia: Improvisation, reinvention and innovation', Built Environment 41 (2015), pp. 478-91.

42 Richard Gale, 'The multicultural city and the politics of religious architecture: Urban planning, mosques and meaning-making in Birmingham, UK', Built Environment 30 (2004), pp. 30-44. AHRC Faith and Place Network, Faith Groups and the Planning System: Policy Briefing (London, University of Roehampton, 2015).

43 Emma Tomalin \& Caroline Starkey, 'Buddhist buildings in England: the construction of 'under-represented' faith heritage in a multicultural and postChristian setting' International Journal of Heritage Studies 23 (2017) pp. 156172; Caroline Starkey \& Emma Tomalin (2016) Building Buddhism in England: The Flourishing of a Minority Faith Heritage, Contemporary Buddhism, 17 (2016), pp. 326-356.

${ }^{44}$ See the Muslim Museum Initiative http://muslimmuseum.org.uk/ and the Everyday Muslim Project http://www.everydaymuslim.org/

45 Ealing Broadway, West Ealing and Hanwell stations are all on the new Crossrail line that will provide fast direct connections to the West End, the City and Docklands from 2019, and which has encouraged both development and wider property inflation.

46 http://www.stjohnandstjames.org.uk/

47 This aspect of suburban creativity in Ealing and the place-making associated with architectural development is explored in David Gilbert, Claire Dwyer, Laura Cuch and Nazneen Ahmed, 'The Sacred and the Suburban: Atmospherics, numinosity and 1930s interiors in Ealing, London', Interiors Design/Architecture/Culture 6 (2015), pp. 211-234.

48 Interview with Nazneen Ahmed and Claire Dwyer, $5^{\text {th }}$ May 2015. See Nazneen Ahmed and Claire Dwyer "Living, changing light': stained glass art and gendered creativity in the suburban church' Culture and Religion (2017). Published online: 27 Sep 2017

${ }^{49}$ Gilbert, Dwyer, Cuch and Ahmed, 'The Sacred and the Suburban'.

50 Pauline Britton interviewed by Claire Dwyer, $30^{\text {th }}$ June 2016; Sheila Burt interviewed by Claire Dwyer, 8 $^{\text {th }}$ July 2016. 
51 Fiona Hackney 'Use your hands for happiness': Home craft and make-do and Mend in British Women's magazines in the 1920s and 1930s' Journal of Design History 19, 1 (2006), pp. 23-38; Fiona Hackney 'Quiet Activism and the New Amateur: the power of home and hobby crafts', Design and Culture 5, pp. 169193.

52 Gilbert, Dwyer, Cuch and Ahmed, 'The Sacred and the Suburban'.

53 Interview with Natalie Hyacinth, 13 ${ }^{\text {th }}$ June 2016.

${ }^{54}$ Interview with Natalie Hyacinth, $19^{\text {th }}$ February 2017.

55 Interview with Natalie Hyacinth, 19th February 2017.

56 See della Dora 'Infrasecular geographies'.

57 Charles Leadbeater and Paul Miller, The Pro-Am Revolution. How Enthusiasts are Changing our Economy and Society (London, Demos, 2004).

58 Thomas Csordas, Language, Charisma, and Creativity. Ritual Life in the Catholic Charismatic Renewal (New York, Palgrave 2001), p. 263. 